\title{
MONETARY POLICY TRANSMISSION MECHANISM OF BANGLADESH
}

In Huh and Yoonsoo Lee

NO. 86

December 2021
ADB SOUTH ASIA WORKING PAPER SERIES 



\section{ADB South Asia Working Paper Series}

\section{Monetary Policy Transmission Mechanism of Bangladesh}

In Huh and Yoonsoo Lee

No. 86 | December 2021
In Huh is an associate professor at the Economics Department, School of Law, Economics, and Public Administration of the Catholic University of Korea. Yoonsoo Lee is a professor at the School of Economics of the Sogang University in the

Republic of Korea. 
(C) 2021 Asian Development Bank

6 ADB Avenue, Mandaluyong City, 1550 Metro Manila, Philippines

Tel +632 8632 4444; Fax +63286362444

www.adb.org

Some rights reserved. Published in 2021.

ISSN 2313-5867 (print), 2313-5875 (electronic)

Publication Stock No. WPS210540-2

DOI: http://dx.doi.org/10.22617/WPS210540-2

The views expressed in this publication are those of the authors and do not necessarily reflect the views and policies of the Asian Development Bank (ADB) or its Board of Governors or the governments they represent.

ADB does not guarantee the accuracy of the data included in this publication and accepts no responsibility for any consequence of their use. The mention of specific companies or products of manufacturers does not imply that they are endorsed or recommended by ADB in preference to others of a similar nature that are not mentioned.

By making any designation of or reference to a particular territory or geographic area, or by using the term "country" in this document, $A D B$ does not intend to make any judgments as to the legal or other status of any territory or area.

This work is available under the Creative Commons Attribution 3.0 IGO license (CC BY 3.0 IGO) https://creativecommons.org/licenses/by/3.0/igo/. By using the content of this publication, you agree to be bound by the terms of this license. For attribution, translations, adaptations, and permissions, please read the provisions and terms of use at https://www.adb.org/terms-use\#openaccess.

This CC license does not apply to non-ADB copyright materials in this publication. If the material is attributed to another source, please contact the copyright owner or publisher of that source for permission to reproduce it. ADB cannot be held liable for any claims that arise as a result of your use of the material.

Please contact pubsmarketing@adb.org if you have questions or comments with respect to content, or if you wish to obtain copyright permission for your intended use that does not fall within these terms, or for permission to use the ADB logo.

The ADB South Asia Working Paper Series is a forum for ongoing and recently completed research and policy studies undertaken in $\mathrm{ADB}$ or on its behalf. It is meant to enhance greater understanding of current important economic and development issues in South Asia, promote policy dialogue among stakeholders, and facilitate reforms and development management.

The ADB South Asia Working Paper Series is a quick-disseminating, informal publication whose titles could subsequently be revised for publication as articles in professional journals or chapters in books. The series is maintained by the South Asia Department. The series will be made available on the ADB website and on hard copy.

Corrigenda to ADB publications may be found at http://www.adb.org/publications/corrigenda.

Notes:

In this publication, "\$” refers to United States dollars and "Tk" refers to taka.

ADB recognizes "Korea" as the Republic of Korea. 


\section{CONTENTS}

TABLES AND FIGURES

iv

ABSTRACT

ABBREVIATIONS vi vi

$\begin{array}{ll}\text { I. INTRODUCTION } & 1\end{array}$

II. KEY VARIABLES AND DATA OF BANGLADESH BANK'S MONETARY POLICY 3

$\begin{array}{ll}\text { III. MODEL AND RESULTS } & \mathbf{7}\end{array}$

A. Estimation Model $\quad 7$

B. Empirical Results of Monetary Policy $\quad 7$

C. Empirical Results of the Effects of National Savings Certificate 13

$\begin{array}{ll}\text { IV. CONCLUSION } & 16\end{array}$

APPENDIX: ALTERNATIVE CHOICE OF VAR LAG ORDER

A. Reserve Money as Policy Variable 17

B. Repo Rate as a Policy Variable $\quad 19$

C. National Savings Certificates as Policy Variable 20

$\begin{array}{lr}\text { REFERENCES } & 21\end{array}$ 


\section{TABLES AND FIGURES}

\section{TABLES}

1 Definition of the Variables in Use $\quad 6$

2 Granger Causality Tests from Reserve Money to Interest Rate, M2, and CPI 9

3 Granger Causality Tests from Interest Rate to M2 and from M2 to CPI 10 (in the Vector Autoregression System of Reserve Money)

4 Granger Causality Tests from Repo Rate to Interest Rate, M2, and CPI 12

5 Granger Causality Tests from Interest Rate to M2 and from M2 to CPI 13 (in the Vector Autoregression System of Repo Rate)

6 Granger Causality Tests from National Savings Certificate 14 to Interest Rate, $\mathrm{M} 2$, and CPI

7 Granger Causality Tests from Interest Rate to M2 and from M2 to CPI 15 (in the Vector Autoregression System of National Savings Certificate)

\section{FIGURES}

1 Bangladesh Money Stocks $\quad 4$

2 Bangladesh Money Multiplier (Money Supply, M2/Reserve Money) 5

3 Bangladesh Repo Rate, Interest, and CPI Inflation 5

4 Bangladesh National Savings Certificates and its Portion to M2 6

5 Impulse of Interest Rate, M2, and CPI to Reserve Money 8

6 Impulse of M2 to Interest Rate and Impulse of CPI to M2 9 (in the Vector Autoregression System of Reserve Money)

7 Paths of Direct and Indirect Impacts of Monetary Policy 10

8 Impulse of Interest Rate, M2, and CPI to Repo Rate 11

9 Impulse of M2 to Interest Rate and Impulse of CPI to M2 12 (in the Vector Autoregression System of Repo Rate)

10 Impulse of Interest Rate, M2, and CPI to National Savings Certificate 14

11 Impulse of M2 to Interest Rate and Impulse of CPI to M2 (in the Vector Autoregression System of National Savings Certificate)

A.1 Impulse of Interest Rate, M2, and CPI to Reserve Money 17

A.2 Impulse of M2 to Interest Rate and Impulse of CPI to M2 18 (in the Vector Autoregression System of Reserve Money)

A.3 Impulse of Interest Rate, M2, and CPI to Repo Rate 19

A.4 Impulse of M2 to Interest Rate and Impulse of CPI to M2 19 (in the Vector Autoregression System of Repo Rate)

A.5 Impulse of Interest Rate, M2, and CPI to National Savings Certificate 20

A.6 Impulse of M2 to Interest Rate and Impulse of CPI to M2 20 (in the Vector Autoregression System of National Savings Certificate) 


\section{ABSTRACT}

The authors empirically analyze the monetary policy transmission mechanism of the economy of Bangladesh. This study analyzes the impacts of reserve money and repo rates on the interest rate, broad money supply (M2), and consumer price index inflation via vector autoregression impulse responses. The authors did not find strong evidence that reserve money and repo rates are effective as monetary policy tools. Also examined were the effects of the issuance of National Savings Certificates (NSCs) on the economy. This study found that the issuance of NSCs affects the interest rate, M2, and inflation in a similar way to open market operation. The findings suggest that government loans via NSCs may weaken the effectiveness of the monetary policy transmission mechanism.

Keywords: Bangladesh economy, monetary policy, National Savings Certificate.

JEL Classification: E5, E4, O5, N2 


\title{
ABBREVIATIONS
}

\author{
AIC - Akaike information criterion \\ $\mathrm{CPI}$ - consumer price index \\ GDP - gross domestic product \\ M2 - money supply \\ NSC - national savings certificate \\ RM - reserve money \\ VAR - vector autoregression
}




\section{INTRODUCTION}

1. Understanding the effects of monetary policy on the economy is crucial in the study of macroeconomics and in the practice of policy making (Boivin, Kiley, and Mishkin 2010; Christiano, Eichenbaum, and Evans 1999; Taylor 1995). In evaluating the effectiveness of monetary policy, it is important to understand the extent to which monetary policy helps to achieve the central bank's objectives. The objectives of the central bank may differ across countries, but in general, price stability is the key mandate. By stabilizing inflation, central banks can make the economic environment more predictable, thereby helping policy makers come up with economic decisions and design stable financial plans. In addition, the objectives of central banks include sustaining economic growth through full employment and maintaining financial market stability. These goals are essential because economic activities are affected by inflation, financial market, and employment volatility.

2. In this paper, the authors empirically examine the effectiveness of the monetary policy of Bangladesh Bank, the central bank in Bangladesh, which has dual objectives of maintaining price stability and supporting sustainable economic growth. Despite the relatively well-defined targets, it is not easy to empirically examine the effectiveness of monetary policy in terms of these objectives (e.g., inflation, gross domestic product [GDP], and unemployment rate). Measuring key macroeconomic variables and gathering timely and reliable data pose some daunting challenges for most developing countries. Moreover, there may be other reasons that are not controllable by the central banks, such as international fiscal shocks, which lead to changes in the policy targets. We statistically test whether the pass-through of monetary policy works by examining the following three variables: quantity of money, interest rates, and inflation. ${ }^{1}$

3. In terms of methodology, we apply time series methods such as vector autoregression (VAR) to examine the relationships between monetary policy tools and the quantity of money, interest rates, and inflation. The impulse responses of the quantity of money, interest rates, and inflation to the monetary policy variables will be used to examine the effectiveness of monetary policy on those variables.

4. Quantifying the effectiveness of monetary policy through these variables is important to an understanding of the monetary policy transmission mechanism. For example, if the quantity of money is not responding to monetary policy, then Bangladesh Bank should consider developing a policy that can ensure that the financial institutions respond to the short-term financial markets, which are directly controllable by the Bangladesh Bank in order to make monetary policy effective. ${ }^{2}$

1 In general, the following six channels of monetary policy transmission are distinguished in the literature: (i) interest rate channel, (ii) bank lending channel, (iii) balance sheet channel, (iv) asset price channel, (v) exchange rate channel, and (vi) expectation channel. The interest rate channel is the most important transmission channel in most advanced countries with financial markets. On the other hand, the exchange rate channel is often considered as the dominant channel of monetary policy transmission in emerging economies (Égert and MacDonald 2009). Due to the lack of available data, we focus on the first channel-interest rate. See Mishra, Montiel, and Spilimbergo (2010) for a more exhaustive discussion of monetary policy transmission channels.

2 In examining the transmission mechanism of monetary policy, central banks are not the only players. Financial institutions also have essential roles in executing monetary policy. The quantity of money is affected by the credit creation activities of financial institutions, including bank lending. For this reason, central banks do not have perfect control over the quantity of money. However, they do control the quantity of money via the short-term financial market. Central banks' authority to issue currencies make them powerful suppliers in overnight lending markets, such as call money markets. By controlling the short-term interest rates, central banks affect the long-term financial markets. 
Moreover, the financial markets in Bangladesh have some idiosyncratic features due to their adherence to the Islamic banking system and the influences of the government (e.g., National Savings Certificate [NSC]). We need to determine whether the pass-through of monetary policy is working or not in order to make plans for the reform or financial market development.

5. This study contributes to the small but growing literature on monetary policy transmission mechanisms in developing countries. Mishra and Montiel (2012) conducted a survey of studies on the effectiveness of monetary policy in developing countries. Although they noted some methodological issues in existing papers, they found that monetary policy transmission appears to be weak in these countries overall. Mishra et al. (2014) found that there is a large variation in the responses of bank lending rates to monetary policy shocks across countries. Khundrakpam and Jain (2012) examined the transmission channels of monetary policy to GDP growth and inflation in India. Their study also found weaker policy transmission in developing countries.

6. There is a dearth of information about the monetary policy transmission mechanism in Bangladesh, with only a limited number of studies on this subject (e.g., Ahmed and Islam 2004; Islam 2012; Goswami and Ahmed 2017; Rahman et al. 2019). Based on VAR analysis of the Bangladeshi economy, Ahmed and Islam (2004) find that bank lending and exchange rate channels are weak. Goswami and Ahmed (2017) find that money supply plays a limited role in affecting inflation, while inflation expectation significantly affects the rate of inflation.

7. One of the challenges in examining the effects of monetary policy is that financial markets are not identical across countries. In particular, financial markets in developing countries are different from those in developed countries. For example, the demand for debt financing in developing countries often exceeds supply. The financial supervising agent then distributes the limited supply to those demanding it. The monetary policies under such restricted situations may have different effects than explained in economic theories. For example, the expansion of the quantity of money may not be possible by merely expanding currency. If the financial markets behave differently to economic theory, monetary policies based on those economic principles may not be effective in controlling the financial market or the macroeconomy.

8. Given such challenges, one key contribution of this paper is to examine the effect of NSCs on the three key objectives of monetary policy. Bangladesh Bank controls the money base, which is also called reserve money (RM). In addition, Bangladesh Bank conducts repo and reverse repo operations. While these aspects - controlling RM and repo operations-are the two key monetary policy tools of Bangladesh Bank, there is an extraordinary financial product that needs to be considered in examining the effects of monetary policy: NSCs. NSCs motivate people to save money; collect small savings; mitigate national budget deficit; and bring particular groups of people like women, senior citizens, people working abroad, and physically handicapped, under a socioeconomic safety net. NSCs also play an important role by reducing foreign aid dependence and money inflation. Due to the attractive interest rates on NSCs, which are often higher than those of government securities or deposit rates of commercial banks, they are popular among the general population as well as among financial investors. ${ }^{3}$

3 NSCs have a higher yield than bank deposits (both short-term and long-term), and have been criticized for their misuse, resulting in growing issuance and high interest costs for the government (IMF 2020). 
For this reason, it is expected that NSCs may affect the aggregate economy in a similar manner as the key monetary policy tool of open market operations - that is, changing the outstanding balance of NSCs may have the same effect as selling and buying government bonds in an open market by a central bank. The authors believe that this empirical analysis will facilitate understanding of policy makers' monetary policy decisions.

\section{KEY VARIABLES AND DATA OF BANGLADESH BANK'S MONETARY POLICY}

9. The objective of this paper is to identify which policy variables could function effectively as monetary policy tools in Bangladesh. The operating targets of Bangladesh Bank are the reserve money (RM) and the broad money supply (M2). Bangladesh Bank has used the cash reserve ratio, the repo facility, the refinancing facility, and other monetary policy tools to inject necessary liquidity into the market. In analyzing the quantity of money, we chose to analyze $M 2$ which comprises financial products including long-term savings. The interest rates in the analysis are average deposit rates that are from the Bangladesh Bank. Consumer price index (CPI) inflation represents inflation in our analysis. We are going to verify whether traditional monetary policy tools, such as reserve money and repo rate, work effectively by examining their effects on money stock, interest rates, and inflation. Moreover, we also examine the effects of NSCs on these variables.

10. In general, we can verify the effectiveness of monetary policy on both the financial market and the real macroeconomy (e.g., GDP and its components). In this paper, focus was on the effects of monetary policy on the financial market of Bangladesh, mainly due to limitations in macroeconomic data. The national account data of Bangladesh are only available at an annual frequency. Moreover, monthly employment data are not available. This is a major drawback because monetary policy may change more frequently, sometimes several times in a year. It is not appropriate to analyze the effects of monetary policy with yearly observations of GDP and its components.

11. The effects of monetary policy are analyzed on the following three variables: inflation, money stocks, and nominal interest rates. Most central banks target inflation. Therefore, inflation is the natural choice for evaluating the effectiveness of monetary policy. M2 was chosen as the money stock to evaluate the effectiveness of the monetary policy. When central banks change their policy, they want to change the money stocks in the economy. Money stocks can be changed not only by central banks, but also by financial institutions. Therefore, determining whether M2 changes along with monetary policy would verify the effectiveness of the policy. The changes in nominal interest rates can also be affected by monetary policy. Monetary policy tools are often limited to the short-term money market. However, long-term interest rates are as important as short-term interest rates for investments and consumption in the economy. Therefore, examining the effects of monetary policy changes on nominal interest rates will help in evaluating the effectiveness of the policy. 
12. The two candidates of monetary policy variables considered in this paper are $\mathrm{RM}^{4}$ and repo rate. In general, central banks have direct control of the RM and repo rate. These two variables are commonly considered by central banks when coming up with monetary policy. In addition to the two traditional tools of monetary policy, we examine the effects of the NSC on the Bangladeshi economy. The Government of Bangladesh directly issues NSCs. The rise in the issuance of NSCs has raised some concern, as this may affect financial market development as well as lead to complications in fiscal policy and debt management (IMF 2018, 2020). The stock of NSCs had risen substantially by the end of 2017, but the issuance of NSCs has been reduced in recent fiscal years in response to government efforts to prevent abuse of the system and reduce borrowing costs. As will be shown by our analysis later, it can be considered as a special policy tool affecting the financial markets in the economy of Bangladesh. It may not be the government's intention to affect the interest rate or money supply by issuing NSCs. However, it is possible that the issuance of NSCs would affect the financial market (regardless of the government's intention) because such a process works in a way that is similar to selling government bonds in open market operations.

13. Figure 1 shows the money stocks of Bangladesh from 2010 to 2018 . Both $M 2$ and RM grow as the size of Bangladesh economy increases. Figure 2 shows the money multiplier, which constitutes $M 2$ over RM. M2 is about 5.1 times as large as RM, but the money multiplier does not show a clear trend over time.

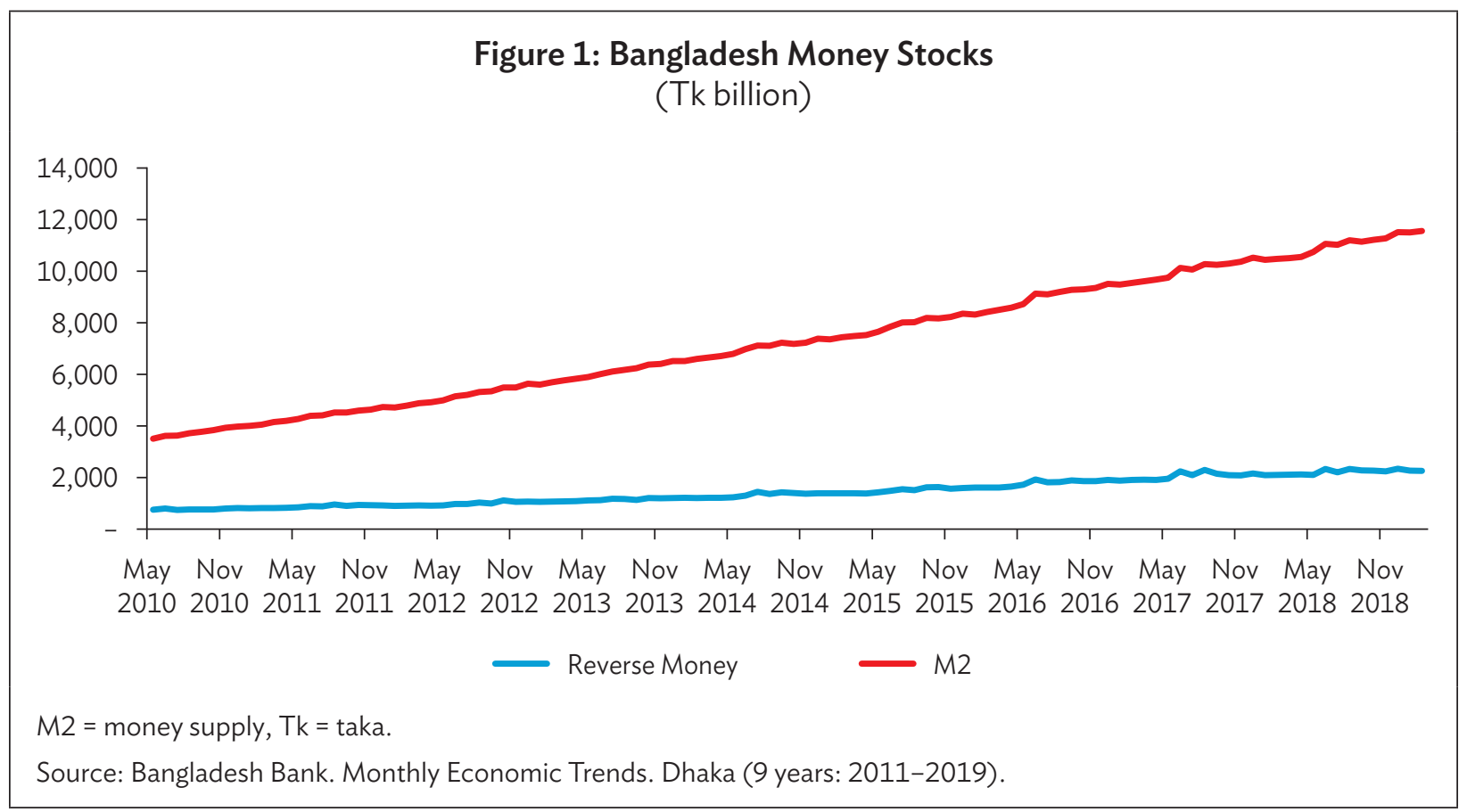

$4 \quad$ The RM is decomposed both in terms of components (liability side) and sources (asset side). In component terms, $\mathrm{RM}=$ currency outside of bank + balance with BB of deposit money banks (DMBs) and other financial institutions + cash in tills of DMBs; and in terms of sources, RM = BB's claims on government (net government credit) + claim on $\mathrm{DMBs}$ (commercial bank borrowing) + net foreign assets. On the other hand, $M 2$ = narrow money $(M 1)+$ time deposits, and $M 1$ = currency + demand deposits. 


\section{Figure 2: Bangladesh Money Multiplier}

(Money Supply, M2/Reserve Money)

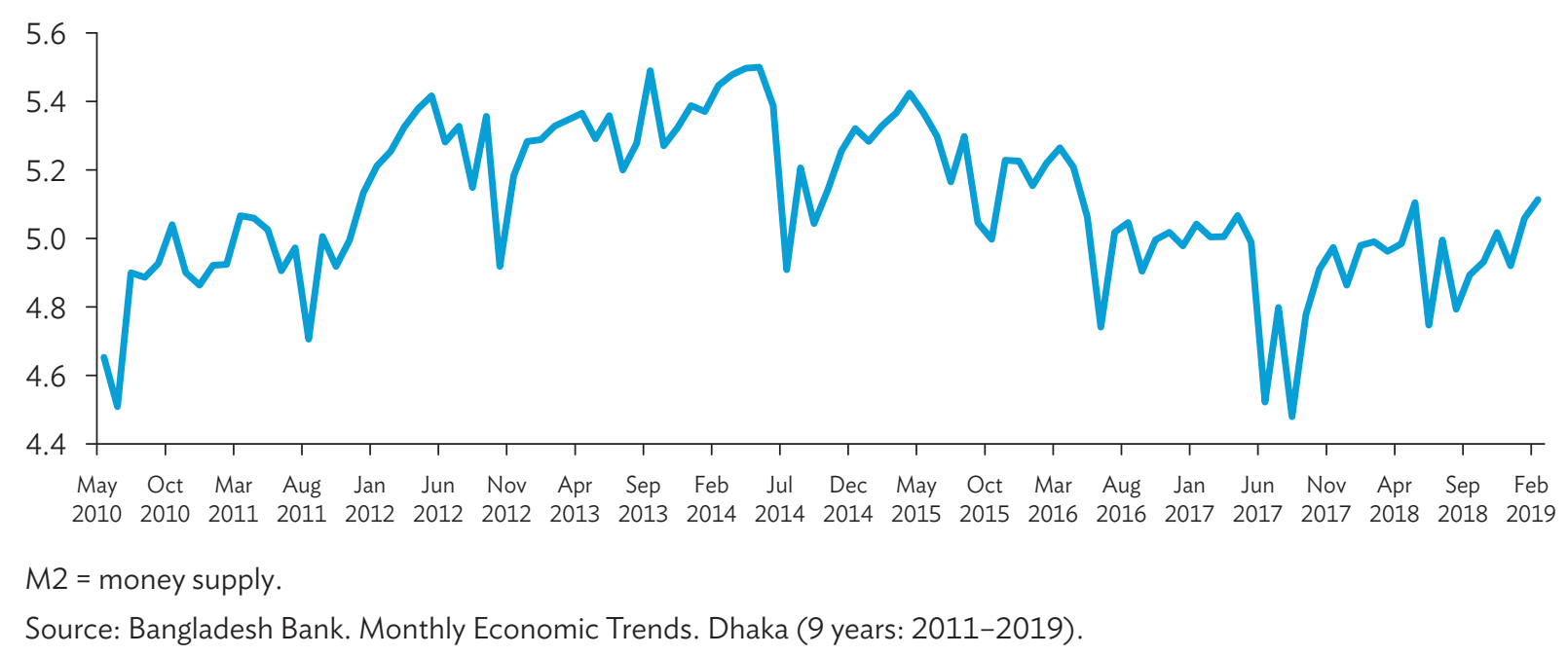

14. Figure 3 shows the repo rate, interest rate, and CPI inflation of Bangladesh. During the sample period, there was an inflation hike up to early 2012. Thereafter, the repo rate increases to control inflation until it stabilizes. Interest rates move together with inflation (co-movement) with some lag, which may suggest that financial market participants exhibit some adoptive behaviors when they forecast inflation. Ex-post real interest rates are positive from 2013 to 2015. For the rest of the sample period, ex-post real interest rates are negative.

Figure 3: Bangladesh Repo Rate, Interest, and CPI Inflation

(\%)

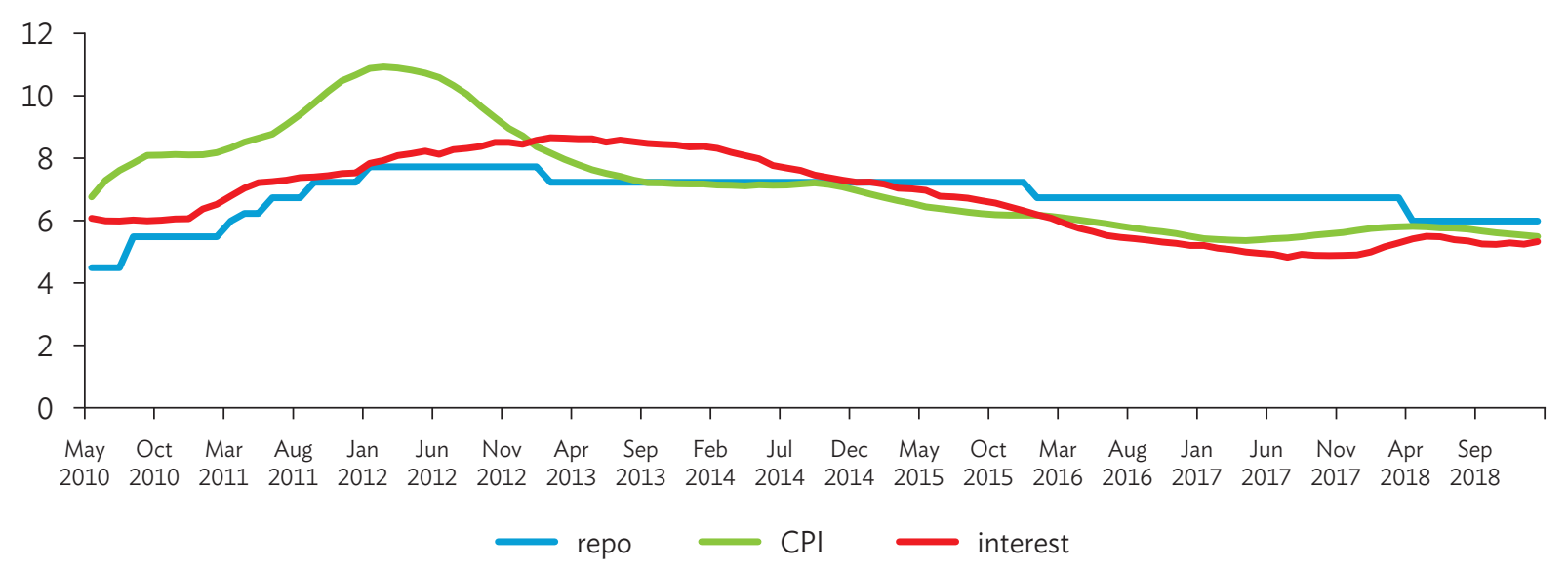

$\mathrm{CPI}=$ consumer price index.

Source: Bangladesh Bank. Monthly Economic Trends. Dhaka (9 years: 2011-2019). 
15. Figure 4 shows the trend of outstanding NSCs, along with the proportion of NSCs in M2. The value of outstanding NSCs increases during the sample period. Until the end of 2013, the proportion of NSCs to M2 decreased to as little as 10.5\%, but steadily increased to 23.6\% by February 2019. Therefore, we can assume that NSCs have played an important role in the money market of Bangladesh until it started decreasing in fiscal year (FY) 2020.

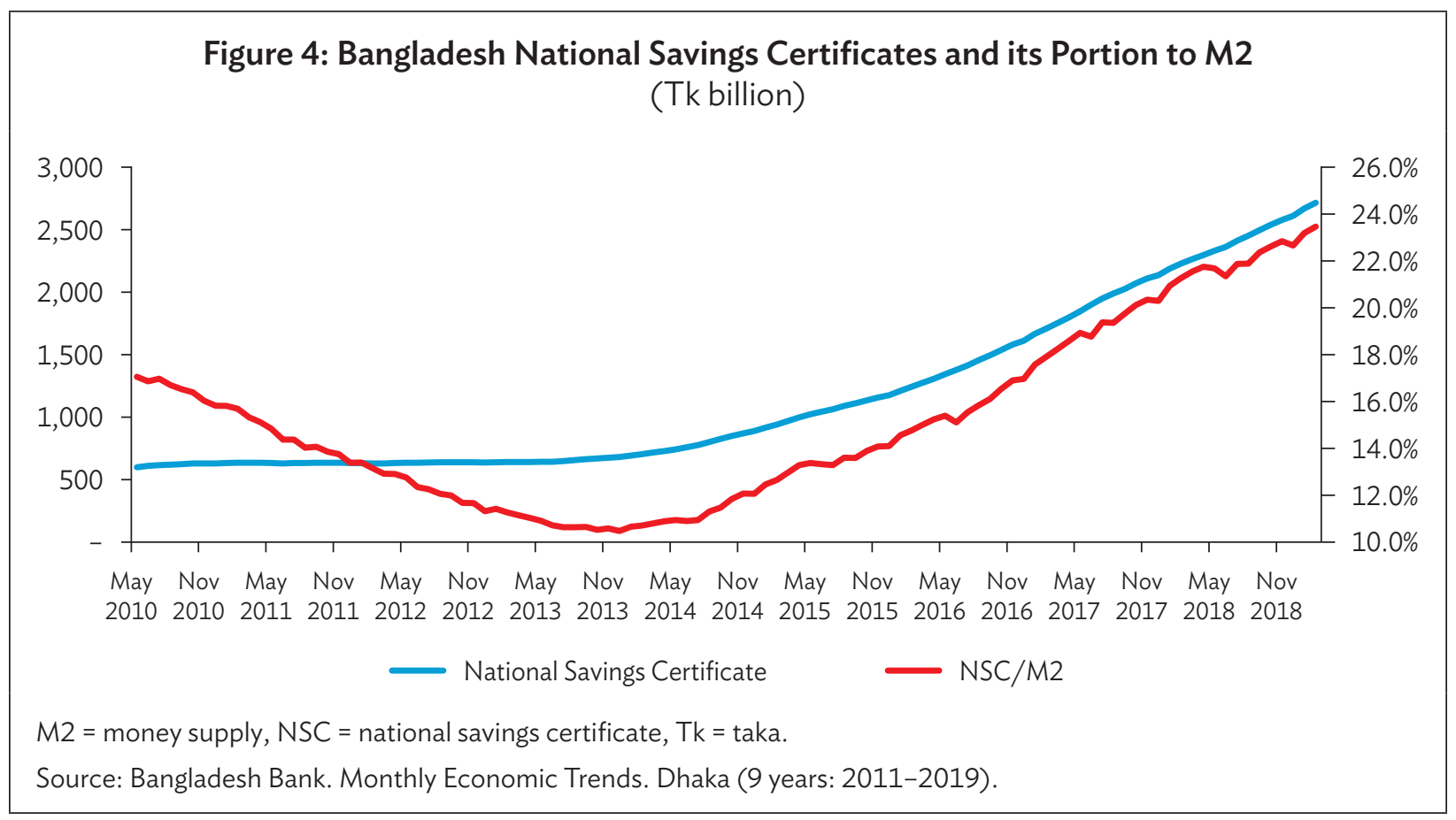

16. For the empirical analysis, we use the first difference in repo rate and interest rate, and percentage changes in money stocks (reserve money and M2) and NSCs. We can identify the dynamics of the variables by using those conversions. Table 1 presents the variable names, their contents, and their sources.

Table 1: Definition of the Variables in Use

\begin{tabular}{lcc}
\hline \multicolumn{1}{l}{ Variable Name } & Contents & Source \\
\hline pc_moneyreserve & \% change in money base (YoY) & Bangladesh Bank \\
\hline d_repo & First difference of repo rate (MoM) & Bangladesh Bank \\
\hline pc_nscertificate & \% change in national savings certificate (MoM) & Bangladesh Bank \\
\hline d_interest & First difference of interest rate (MoM) & Bangladesh Bank \\
\hline pc_M2 & $\%$ change in M2 (YoY) & Bangladesh Bank \\
\hline cpi & $\%$ change in consumer price index (YoY) & Bangladesh Bank
\end{tabular}

M2 = money supply, MoM = month-on-month, YoY = year-on-year.

Sources: Bangladesh Bank. Monthly Economic Trends. Dhaka (9 years: 2011-2019); authors' calculation. 


\section{MODEL AND RESULTS}

\section{A. Estimation Model}

17. We set up the VAR (vector autoregression) model as:

$$
Y_{t}=\sum_{i=1}^{12} A_{i} Y_{t-i}+\varepsilon_{t}
$$

where $Y_{t}$ is the vector of variables in the order of policy, interest rate, $\mathrm{M} 2$, and inflation; and $A_{i}$ are the matrices of the coefficients. We set the lag to 12 since the data are observed monthly. We include a year's lag to consider the lagging effect of monetary policy.

18. We also report the Granger causality test results from the policy variables to the interest rate, M2, and inflation. The Granger causality test was conducted using the F-test. For example, let us assume that there are three variables in the VAR model above: RM, interest rate, and $M 2$. After we separate the VAR model by the dependent variables, we pick the equation for M2. It then becomes:

$$
M 2_{t}=\sum_{i=1}^{12} a_{i} M 2_{t-i}+\sum_{i=1}^{12} b_{i} R M_{t-i}+\sum_{i=1}^{12} c_{i} i_{t-i}+\varepsilon_{M 2, t}
$$

where RM is the money reserve and $i$ is the interest rate. In order to test whether the RM Granger causes $\mathrm{M} 2$, we jointly test $\mathrm{HO}: b_{i}=0, \forall i$, which can be done by the F-test through running the restricted regression under $\mathrm{H} 0$.

\section{B. Empirical Results of Monetary Policy}

\section{Reserve Money as Policy Variable}

19. First, we consider reserve money (RM) as a monetary policy variable. As described by Bangladesh Bank, the quantity of RM is controlled to maintain the quantity of M2. This is the key policy tool of Bangladesh Bank. The following graphs are the impulse response curves of VAR with $90 \%$ confidence intervals.

20. Figure 5 presents the impulse response of the interest rate, $M 2$, and CPI to changes in the RM level. From the impulse response to a positive shock (i.e., expansionary policy), RM only impacts the interest rate. However, the direction of the effect is not consistent with the prediction of monetary theory. Instead of decreasing the interest rate, a positive shock to RM actually increases it. Such a result may be justified if the financial market participants expect that the inflation effects (of money supply) would dominate liquidity effects. In general, the central bank's intention to ease the money supply is intended to expand the economy by encouraging investment and consumption (via lowering interest rates). 
However, the impulse response results in Figure 5 suggest that the usual transmission mechanism of monetary policy by adjusting RM may fail to work because of the unexpected effect on interest rates. ${ }^{5}$

Figure 5: Impulse of Interest Rate, M2, and CPI to Reserve Money
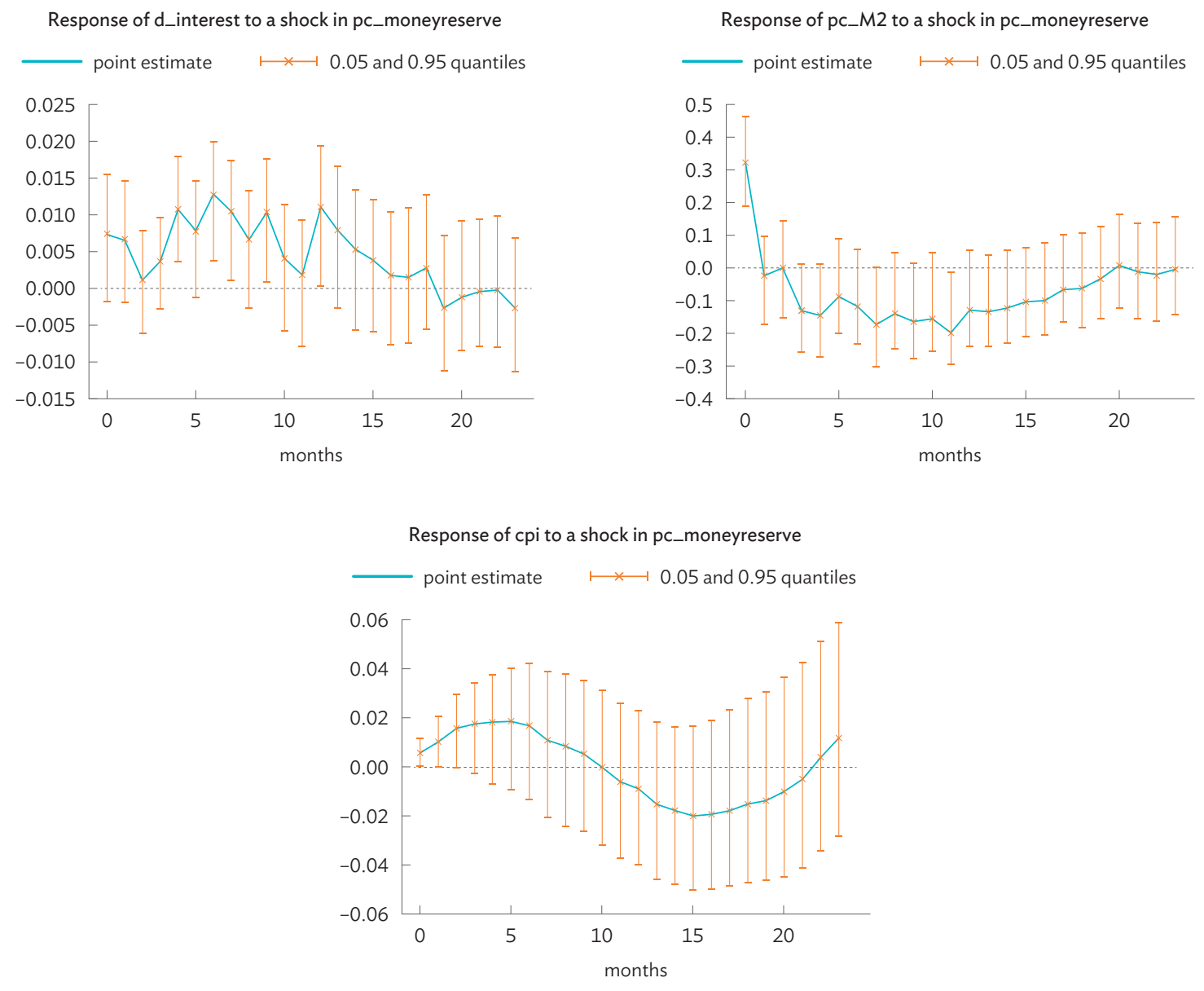

$\mathrm{CPI}=$ consumer price index, $\mathrm{M} 2$ = money supply.

Source: Authors' estimation.

$5 \quad$ Unlike the results for interest rate or $\mathrm{M} 2$, the confidence intervals for the response of $\mathrm{CPI}$ seem to explode during the 2-year period in the plot. The CPI of Bangladesh economy appears to be a long memory process and behaves in a similar way to a variable with unit root. Please note that the variable in the analysis is percentage change, which is close to the first difference of log. For a purely statistical purpose to resolve this issue, we may take the second difference of CPI. However, we don't have any theoretical ground to do so (for example, the quantity equation of MV = PY suggests taking the first difference for money supply and price). 
21. Table 2 shows the test results of Granger causality from RM to other nominal variables in the VAR system. ${ }^{6}$ They also confirm the findings from the impulse responses; RM had a statistically significant impact only on interest rates (at a 5\% significance level).

Table 2: Granger Causality Tests from Reserve Money to Interest Rate, M2, and CPI

\begin{tabular}{cccc}
\hline Null Hypothesis & RM $\neq$ interest rate & RM $\neq$ M2 & RM $\nrightarrow$ CPI \\
\hline F-test statistics & 2.29 & 1.46 & 1.80 \\
\hline (P-value) & $(0.02)$ & $(0.18)$ & $(0.08)$ \\
\hline
\end{tabular}

$\mathrm{CPI}=$ consumer price index, $\mathrm{M} 2$ = money supply, $\mathrm{RM}=$ reserve money.

Source: Authors' estimation.

22. To check if there are indirect impacts to $M 2$ and inflation from $R M$, the impulses of $M 2$ and $C P I$ to interest rate and $M 2$, respectively, are shown in Figure 6. ${ }^{7}$

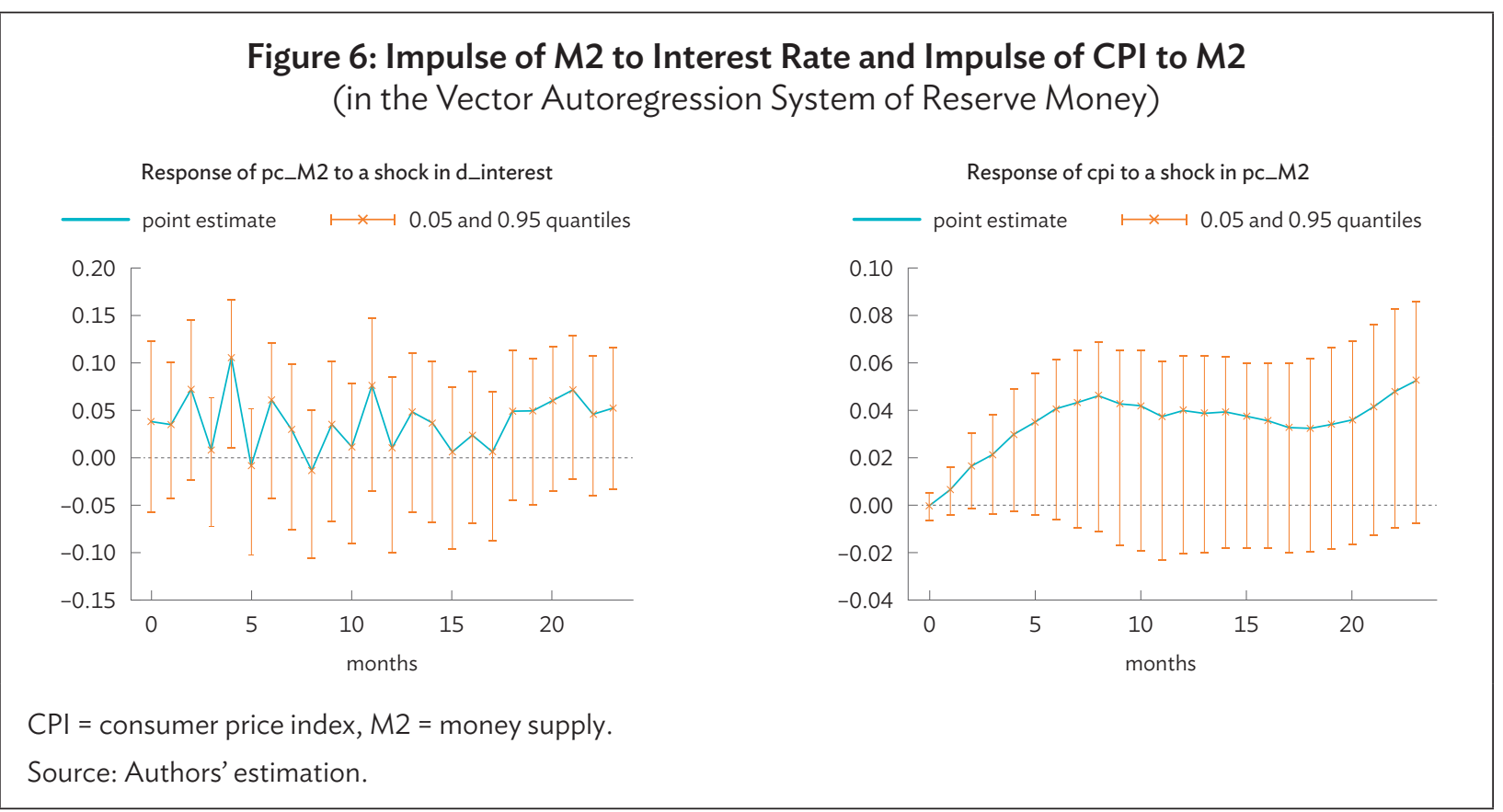

6 Granger causality tests only the statistical significances of lagged variables' coefficients and not their signs (directions). Moreover, the impulse responses show the accumulated effects of the lagged variables. Therefore, even if the Granger causality test shows insignificant coefficients, the accumulated effects can be significant.

7 As in Figure 5, the response of CPI diverges over time. The CPI of Bangladesh economy appears to be a long memory process. See footnote 5 . 
23. The monetary policy variable, which is reserve money in this section, can have a direct impact on interest rates, $\mathrm{M} 2$, and $\mathrm{CPI}$, which are expressed as black arrows in Figure 7. It can have an indirect impact on them if there are significant impacts from interest rates to $M 2$ and/or from $M 2$ to CPI (expressed as red arrows in Figure 7). There are hardly any significant impacts on both variables. According to these results, we cannot expect RM to have any indirect effects on monetary policy.

Figure 7: Paths of Direct and Indirect Impacts of Monetary Policy

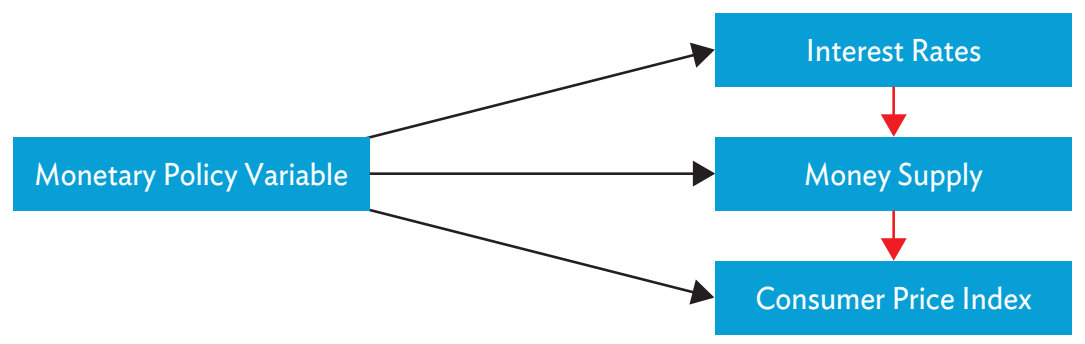

Source: Bangladesh Bank. Monthly Economic Trends. Dhaka (9 years: 2011-2019).

24. The Granger causality tests confirmed that there is no Granger causality from interest rate to M2. However, there is evidence of Granger causality from M2 to CPI. The reason why this does not show in the impulse is that the estimated coefficients from M2's lags have different signs. Some statistically significant coefficients have positive signs, while others have negative signs. The total effect from the lags of $M 2$ to $C P I$ becomes statistically insignificant, similar to the impulse response.

Table 3: Granger Causality Tests from Interest Rate to $M 2$ and from $M 2$ to CPI

(in the Vector Autoregression System of Reserve Money)

\begin{tabular}{ccc}
\hline Null Hypothesis & Interest rate $\nrightarrow \mathrm{M} 2$ & $\mathrm{M} 2 \nrightarrow \mathrm{CPI}$ \\
\hline F-test statistics & 1.28 & 2.71 \\
\hline$($ P-value $)$ & $(0.26)$ & $(0.01)$ \\
\hline
\end{tabular}

$\mathrm{CPI}=$ consumer price index, M2 = money supply.

Source: Authors' estimation.

\section{Repo rate as a policy variable}

25. The second policy variable considered is the repo rate. The impulses reported in Figure 8 suggests that a positive shock to repo rates (i.e., contractionary monetary policy) has a marginally significant impact on interest rates in the second month. An increase in the repo rate causes a corresponding increase in the interest rate. Although a shock to the repo rate impacts inflation significantly, the impact is not immediate and is not consistent with the prediction of economic theory. Tightening the money supply by increasing the repo rate should decrease (not increase, as shown in the figure) inflation. 


\section{Figure 8: Impulse of Interest Rate, M2, and CPI to Repo Rate}
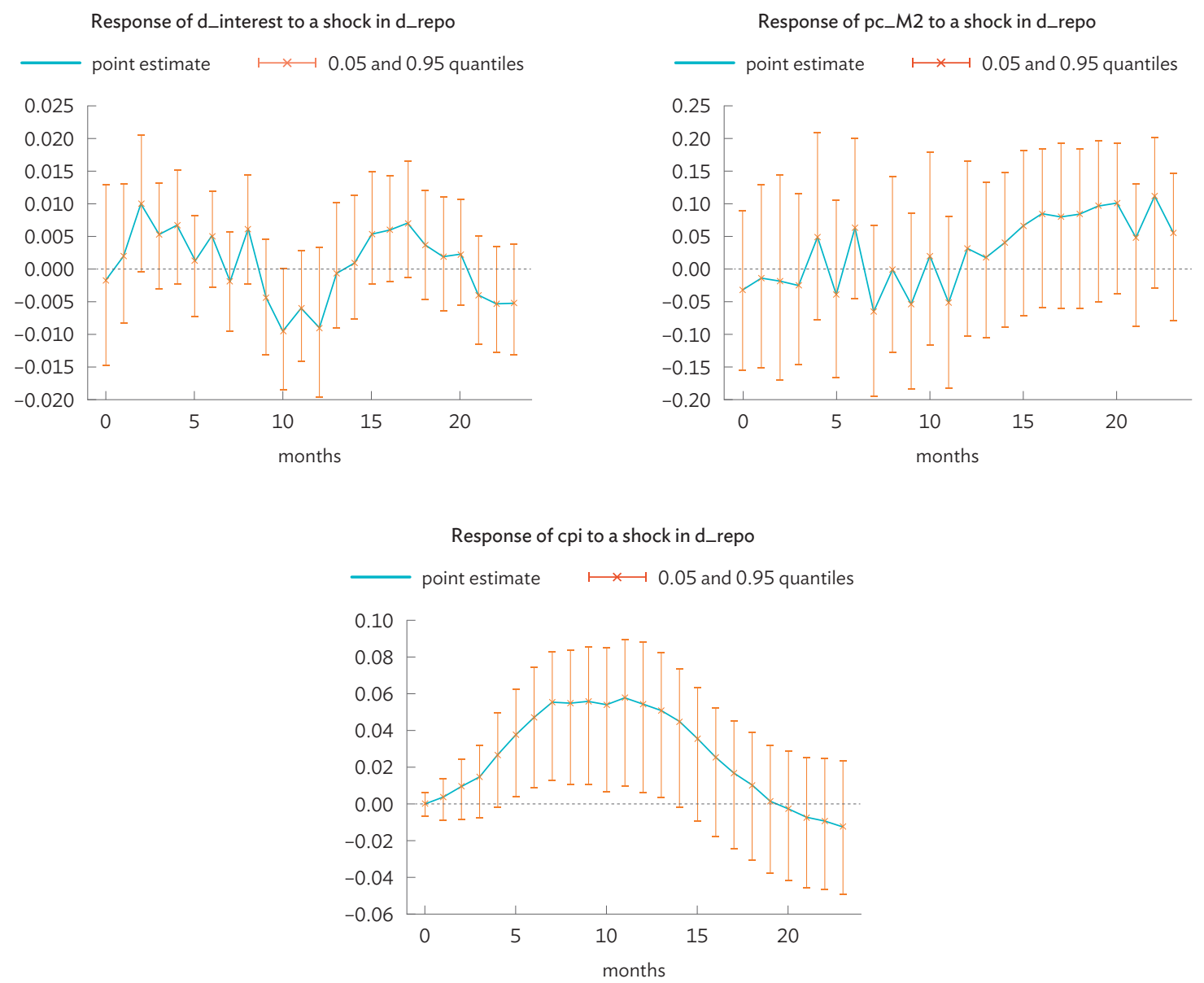

$\mathrm{CPI}=$ consumer price index, $\mathrm{M} 2$ = money supply.

Source: Authors' estimation.

The shock to the repo rate does not have an impact on $M 2$. These results suggest that the change in repo rates may not have worked in accordance with the central bank's intention (i.e., a target of monetary policy). By increasing the repo rates, which, in turn, tightens liquidity, the central bank wants to subdue inflation pressure. Therefore, the central bank's action of changing the repo rate has not been effective during the sample period. ${ }^{8}$

8 The response of inflation to repo shock in Figure 8 is not quite intuitive. While this can be interpreted as a lack of monetary policy transmission, it could be due to the VAR choice and variables included in the analysis. Such pattern is called the "price puzzle" in VARs - a rise in the aggregate price level in response to a contractionary shock to monetary policy. See Hanson (2004) or Giordani (2004). 
26. The Granger causality test is shown in Table 4. The results are compatible with the impulse responses. The repo rate has a statistically significant impact on CPI. As shown in the impulse, the statistically significant coefficients of the repo rates' lags are found from the fourth month at a 5\% significance level. This is why the significant impulse is evident in later months. However, the direction of impact from repo rate to CPI is positive, which is not consistent with the prediction of monetary theory (and the intention of the central bank).

Table 4: Granger Causality Tests from Repo Rate to Interest Rate, M2, and CPI

\begin{tabular}{cccc}
\hline Null Hypothesis & Repo rate $\boldsymbol{f}$ interest rate & Repo rate $\neq$ M2 & Repo rate $f$ CPI \\
\hline F-test statistics & 0.85 & 0.51 & 2.60 \\
\hline (P-value) & $(0.60)$ & $(0.90)$ & $(0.01)$ \\
\hline
\end{tabular}

$\mathrm{CPI}=$ consumer price index, $\mathrm{M} 2$ = money supply.

Source: Authors' estimation.

27. To check the indirect impact of the repo rate, Figure 9 presents the impulse of $M 2$ to the interest rate, and that of $C P I$ to $M 2$. We find a significant impact of interest rate on $M 2$. An increase in interest rate reduces $M 2$. Moreover, an increase in $M 2$ increases inflation. These results are consistent with the prediction of monetary theory. Therefore, since the repo rates have a marginally significant impact on interest rates, we may conclude that controlling the repo rates may work effectively through the interest rate channel.

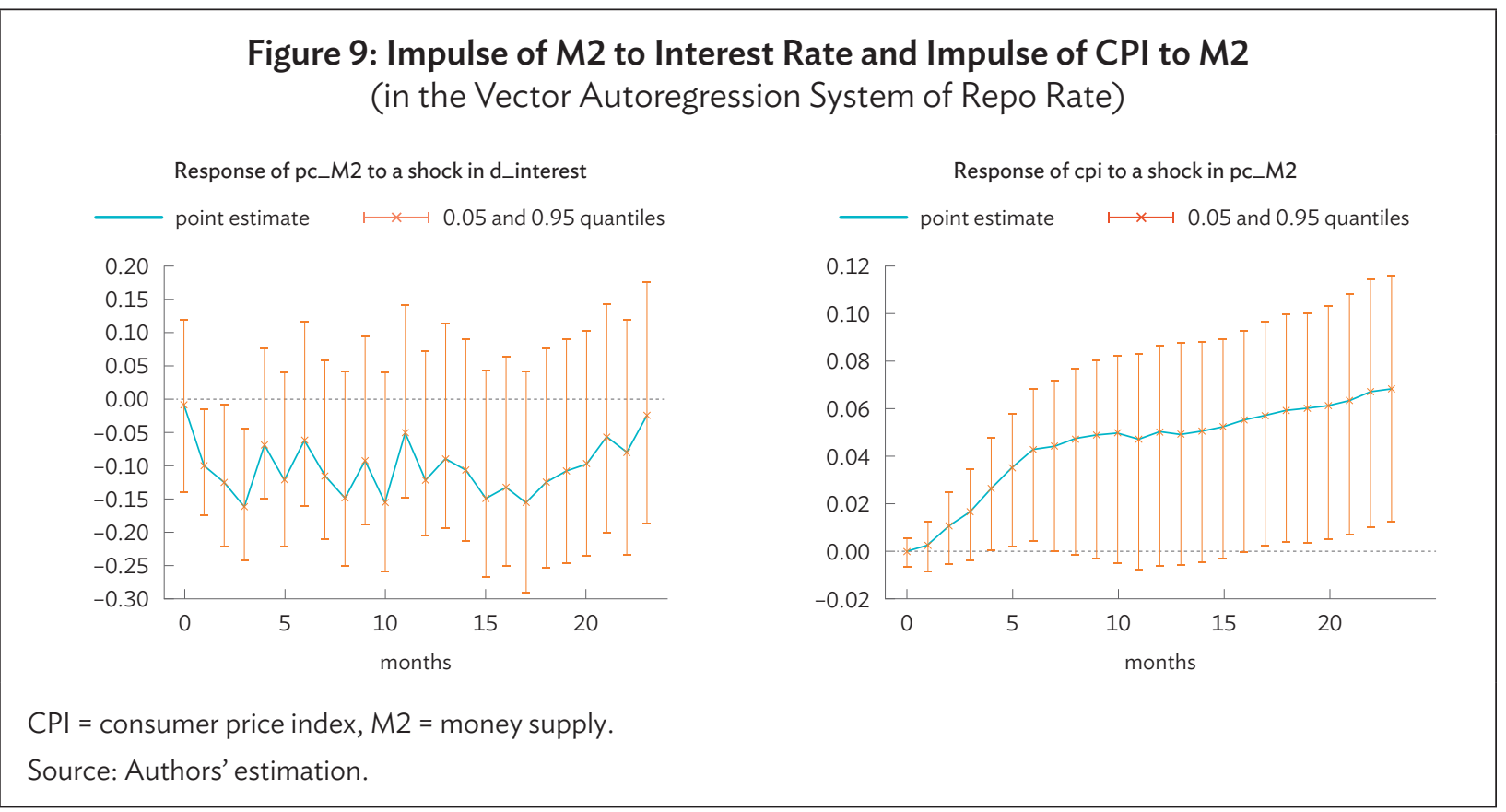


28. However, the Granger causality tests in Table 5 do not indicate any statistically significant results from interest rate to $M 2$ or from $M 2$ to $C P I$. The impulse and Granger causality tests could have shown different results since the jointly added coefficients of lags in the impact variables could be statistically significant while the individual coefficients of the lags are not.

Table 5: Granger Causality Tests from Interest Rate to $M 2$ and from $M 2$ to CPI (in the Vector Autoregression System of Repo Rate)

\begin{tabular}{ccc}
\hline Null Hypothesis & Interest rate $f$ M2 & M2 $f$ CPI \\
\hline F-test statistics & 0.80 & 0.97 \\
\hline (P-value) & $(0.65)$ & $(0.49)$ \\
\hline
\end{tabular}

$\mathrm{CPI}=$ consumer price index, $\mathrm{M} 2$ = money supply.

Source: Authors' estimation.

29. In summary, we conclude that there is a marginal impact of the repo rate on the quantity of money (M2) and inflation via the interest rate channel. However, the direct impact of repo rates on M2 and inflation is not necessarily consistent with monetary theory or monetary policy intentions.

\section{Empirical Results of the Effects of National Savings Certificate}

30. In this section, we consider the effect of NSCs on interest rates, money supply, and inflation. The NSC is not a monetary policy instrument. It is a high-yield debt issued by the Ministry of Finance and could be deemed as part of fiscal policy. As a matter of fact, Bangladesh Bank has no control over its issuance. However, because of its higher interest rates than bank deposits, its issuance has a negative impact on deposits and, therefore, bank credit. ${ }^{9}$ For this reason, NSCs might have distorted the relationship between monetary policy instruments and their intended targets. We examine the extent to which NSCs have affected the key macro variables. From the impulses in Figure 10 (with 90\% confidence intervals), we find that a shock to NSCs has a significant impact on all three variables. An increase in shock to NSCs decreases M2 and inflation. Even though it also affects interest rates (decreasing), the persistence and significance of impacts are much greater on $\mathrm{M} 2$ and inflation.

31. However, we do not find any statistically significant test results of Granger causality in Table 6. The reason we see the differences is that the jointly added coefficients of the lags of impact variables could be statistically significant, while individual coefficients are not.

$9 \quad$ NSC also has significant fiscal costs due to higher interest rates. See IMF staff report (2018) for the issues related to the NSC in Bangladesh. 


\section{Figure 10: Impulse of Interest Rate, M2, and CPI to National Savings Certificate}

Response of d_interest to a shock in pc_nscertificate

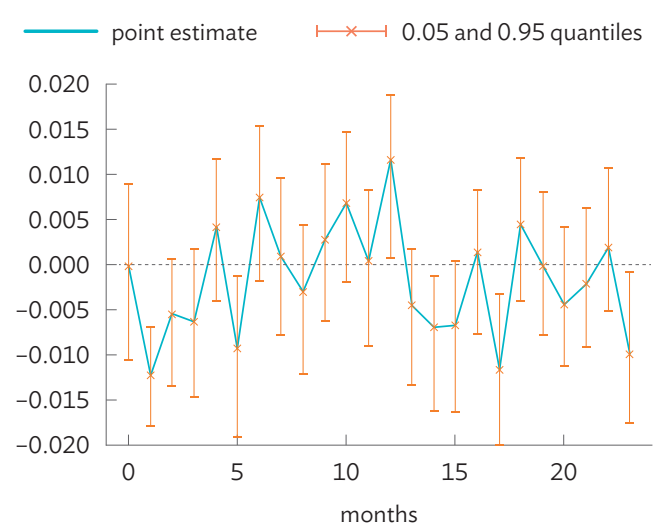

Response of pc_M2 to a shock in pc_nscertificate

point estimate $\longmapsto 0.05$ and 0.95 quantiles

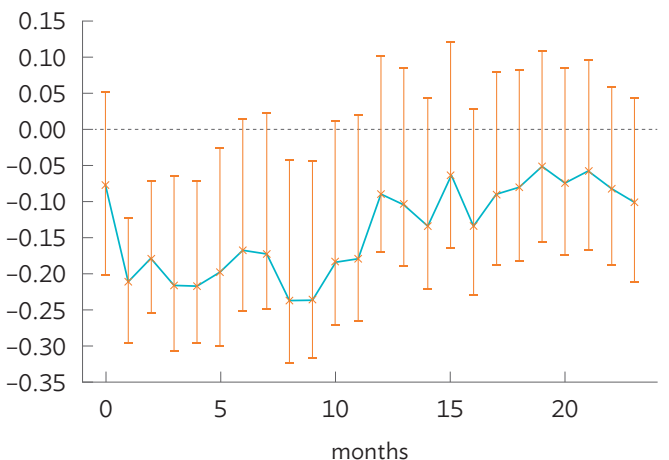

Response of cpi to a shock in pc_nscertificate

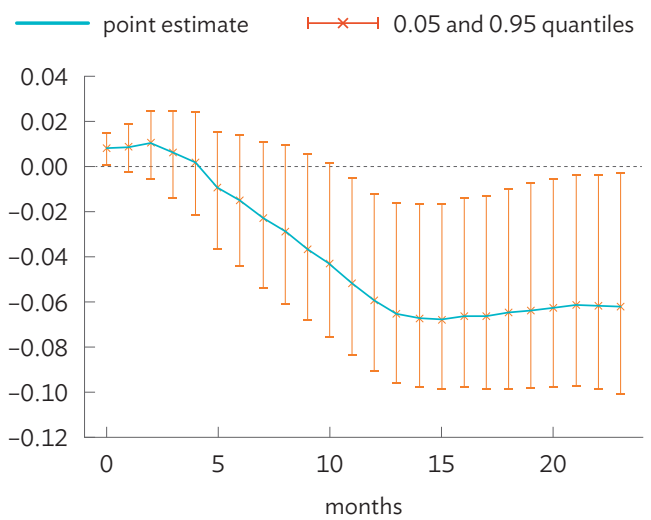

$\mathrm{CPI}=$ consumer price index, M2 = money supply, NSC = national savings certificate .

Source: Authors' estimation.

Table 6: Granger Causality Tests from National Savings Certificate to Interest Rate, $\mathrm{M} 2$, and CPI

\begin{tabular}{cccc}
\hline Null Hypothesis & $\begin{array}{c}\text { National savings } \\
\text { certificate } \boldsymbol{f} \text { interest rate }\end{array}$ & $\begin{array}{c}\text { National savings } \\
\text { certificate } \boldsymbol{\phi} \mathbf{M 2}\end{array}$ & $\begin{array}{c}\text { National savings } \\
\text { certificate } \boldsymbol{f} \text { CPI }\end{array}$ \\
\hline F-test statistics & 1.44 & 1.66 & 0.61 \\
\hline (P-value) & $(0.19)$ & $(0.11)$ & $(0.83)$ \\
\hline
\end{tabular}

$\mathrm{CPI}=$ consumer price index, $\mathrm{M} 2$ = money supply.

Source: Authors' estimation. 
32. To check the indirect impact of NSCs, Figure 11 shows the response of $M 2$ to interest rate shock. An increase in interest rate reduces $M 2$. Moreover, an increase in $M 2$ increases inflation. These two results are consistent with the prediction of monetary theory (i.e., the prediction of open market operation). Given that the two traditional policy variables, money reserve and repo rate, do not have an expected direct effect, whereas NSCs do, there is a possibility that NSCs may have an important role in financial markets, although this is not the intention of the government and the central banks.

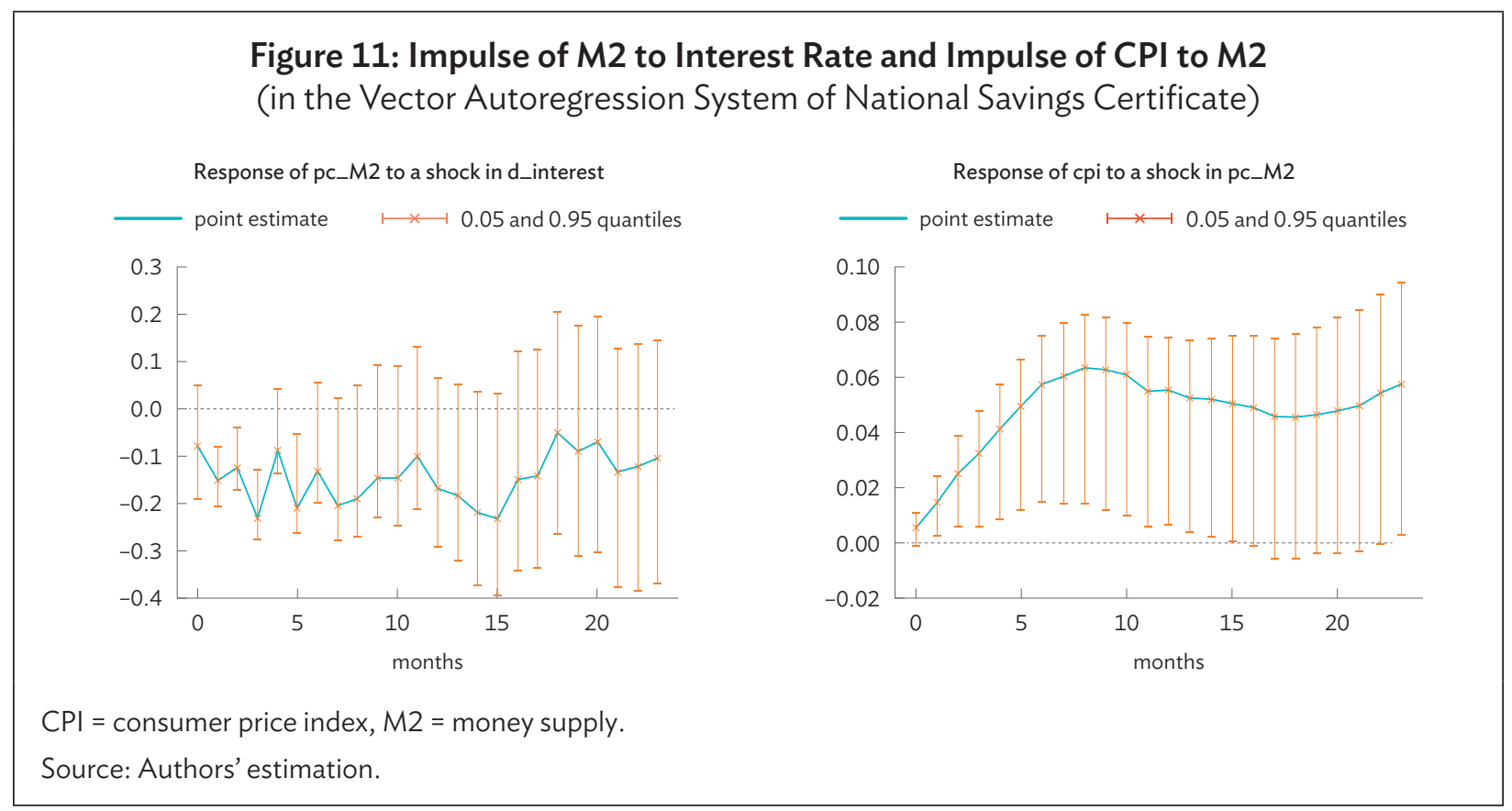

33. However, we do not find statistically significant Granger causality test results in Table 7. The reason why we find different results from impulse to Granger causality can be ascribed to the same explanations as those for Figure 10 and Table 6. To sum up, both direct and indirect impacts of NSCs on interest rates, M2, and inflation are significant and work just like an open market operation of security trading of a central bank.

Table 7: Granger Causality Tests from Interest Rate to $M 2$ and from $M 2$ to CPI (in the Vector Autoregression System of National Savings Certificate)

\begin{tabular}{ccc}
\hline Null Hypothesis & Interest rate $f \mathbf{M} 2$ & $\mathrm{M} 2 \neq \mathrm{CPI}$ \\
\hline F-test statistics & 1.86 & 1.37 \\
\hline (P-value) & $(0.07)$ & $(0.22)$ \\
\hline
\end{tabular}

$\mathrm{CPI}=$ consumer price index, $\mathrm{M} 2$ = money supply.

Source: Authors' estimation. 


\section{CONCLUSION}

34. In examining the effectiveness of the monetary policy on the economy of Bangladesh, we find that the traditional tools (i.e., reserve money and repo rate) do not perform as predicted by textbook monetary theory. For example, increasing the reserve money and lowering the repo rate does not increase $\mathrm{M} 2$ or inflation (at least not directly). Such results are not consistent with the monetary easing effects in monetary theory.

35. Some studies find that monetary policy transmission is relatively weak in developing countries (for example, Mishra and Montiel [2012]). However, it is not clear why the usual monetary policy transmission mechanism is not working properly in Bangladesh. Such results may be attributed to the country's different banking systems. For example, changes in reserve money may not have enough impact on the balance sheet of commercial banks in Bangladesh, or the changes in repo rate may not have an impact on the lending behavior of commercial banks. The difference might be caused by the Islamic banking system, which accounts for a substantial part of the banking sector in Bangladesh. It might also be caused by the relatively small size of the financial markets or the underdeveloped asset markets of the Bangladesh economy, which make it difficult for monetary policy to work in the financial markets.

36. While the other monetary policy tools have been shown to have no significant impact on the monetary systems in Bangladesh, the NSC affects the Bangladesh economy as if it were a monetary policy tool. The relatively large role of the government in Bangladesh makes NSCs important in the Bangladesh monetary system. Overall, our findings suggest that government borrowing via NSC may weaken the effectiveness of the monetary policy transmission mechanism. We find that NSCs have a significant impact on $\mathrm{M} 2$ and inflation. Moreover, the effects of NSCs on the transmission mechanism are quite consistent with the prediction of open market operations.

37. NSCs are primarily a source of government funding and account for an important portion of the national debt (just like Treasury bonds or bills). Although the issuance of NSCs was a major source of financing in previous years, they have attracted criticism in complicating fiscal policy and debt management. Our new finding reveals that NSCs may not only distort fiscal policies, but also disrupt the central bank's ability to affect interest rates. In addition to the possibility of crowding out private investments, the issuance of NSCs in large quantities may cause an increase in interest rates, thereby tampering with the central bank's ability to control the interest rate. In light of this finding, the government should practice caution when issuing NSCs. Recent government efforts to prevent abuse of NSCs and reform the system have led to a reduction in their issuance. Such reform should continue further so that the domestic debt market and the financial market have more space to develop. Well-functioning bond markets will also help Bangladesh to develop its pension system. Because institutional investors such as pension funds need to hold long-term debt, the development of debt markets is crucial.

38. Finally, moving toward a rule-based interest rate-targeted policy with market-based monetary instruments will improve the transmission of monetary policy. The current practice of Bangladesh Bank monetary policy is focused on the money supply. Better monitoring and forecasting of changes in liquidity, as well as the development of a well-functioning money market, are essential steps in moving forward to an interest rate targeted policy. Moreover, a well-developed capital market will help to boost economic growth of Bangladesh. 


\section{APPENDIX: ALTERNATIVE CHOICE OF VAR LAG ORDER}

1. In all vector autoregression (VAR) analyses in the main text, we apply the Akaike information criterion (AIC) to choose the number of lags. The maximum number of lags to consider was 12 . According to AIC, the number of lags in all VAR analyses was selected to be 12 .

2. However, the appropriate number of lags in VAR was 2 in the VAR systems according to the Schwarz and Hannan-Quinn models. The following shows the impulse responses when we choose the number of lags to be 2 , along with the impulse responses with 12 lags. Overall, the direction of impulse responses did not change, but the $90 \%$ confidence interval grew (except the impulse of consumer price index [CPI] to policy variables and money supply [M2]). In the VAR with National Savings Certificates (NSCs), the reduced number of lags does not have a statistically significant impact, and the direction of impulse responses does not change.

3. In general, including a larger lag is more accurate than a smaller one, since missing variables introduce inconsistencies in the estimations. Since we get more narrow impulses with a larger lag, we choose to report VAR results with the larger lag in the main text. For comparison purposes, we replicate figures from the main text (we keep the same figure numbers).

\section{A. Reserve Money as Policy Variable}

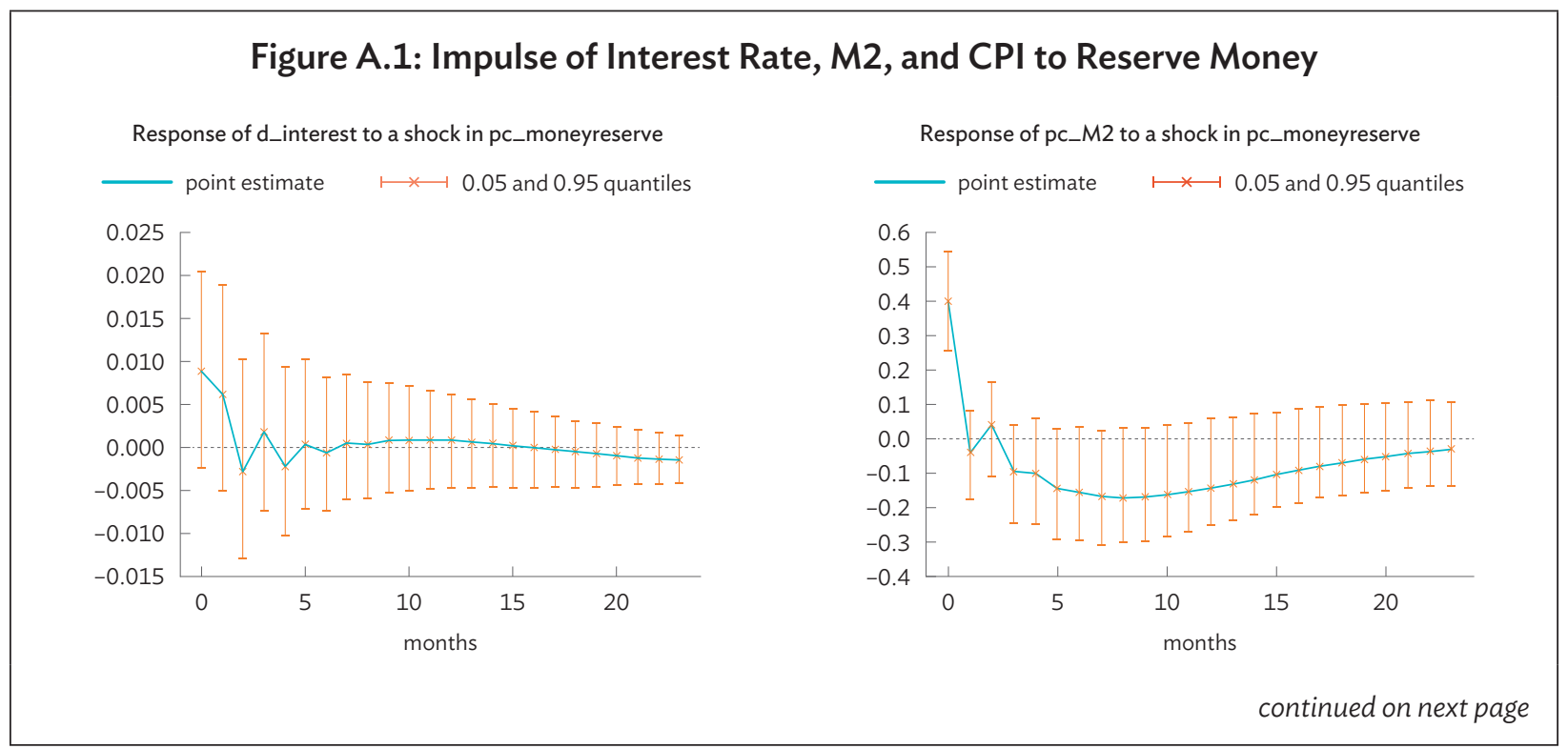




\section{Figure A.1: Continued}

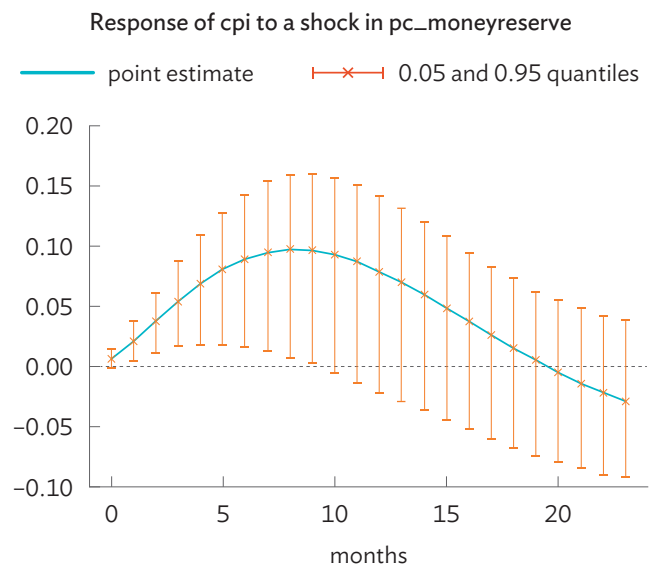

$\mathrm{CPI}=$ consumer price index, $\mathrm{M} 2$ = money supply.

Source: Authors' estimation.

Figure A.2: Impulse of M2 to Interest Rate and Impulse of CPI to M2 (in the Vector Autoregression System of Reserve Money)
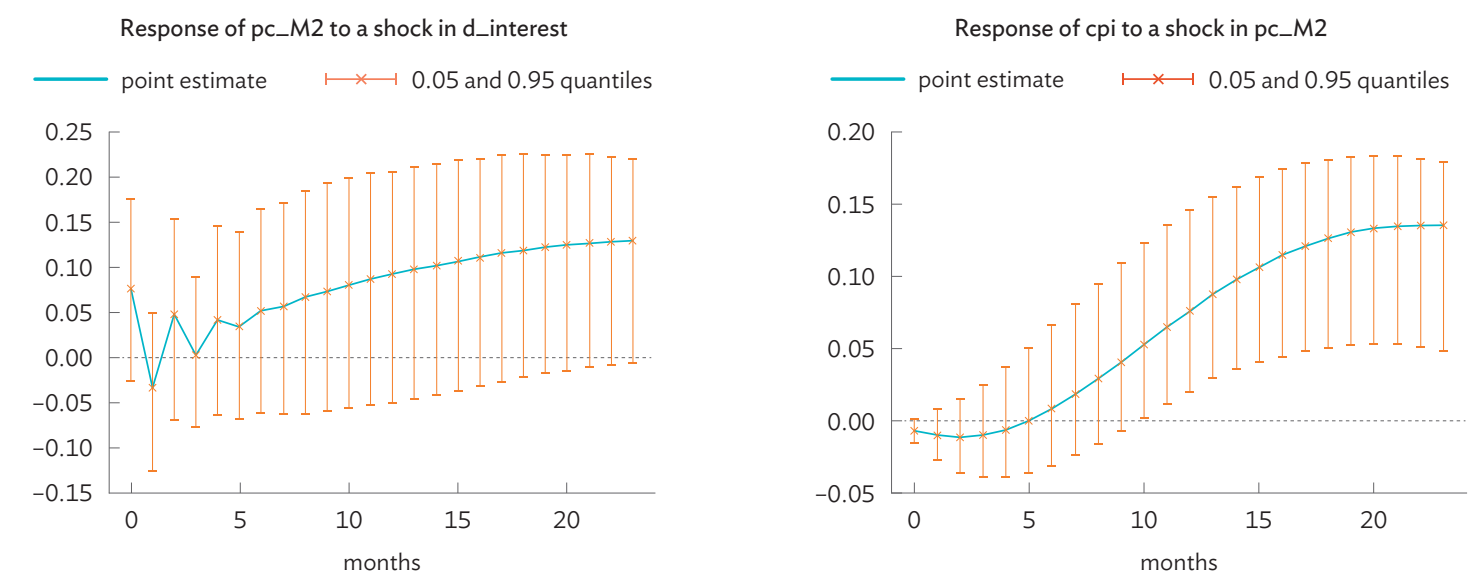

$\mathrm{CPI}$ = consumer price index, $\mathrm{M} 2$ = money supply.

Source: Authors' estimation. 


\section{B. Repo Rate as a Policy Variable}
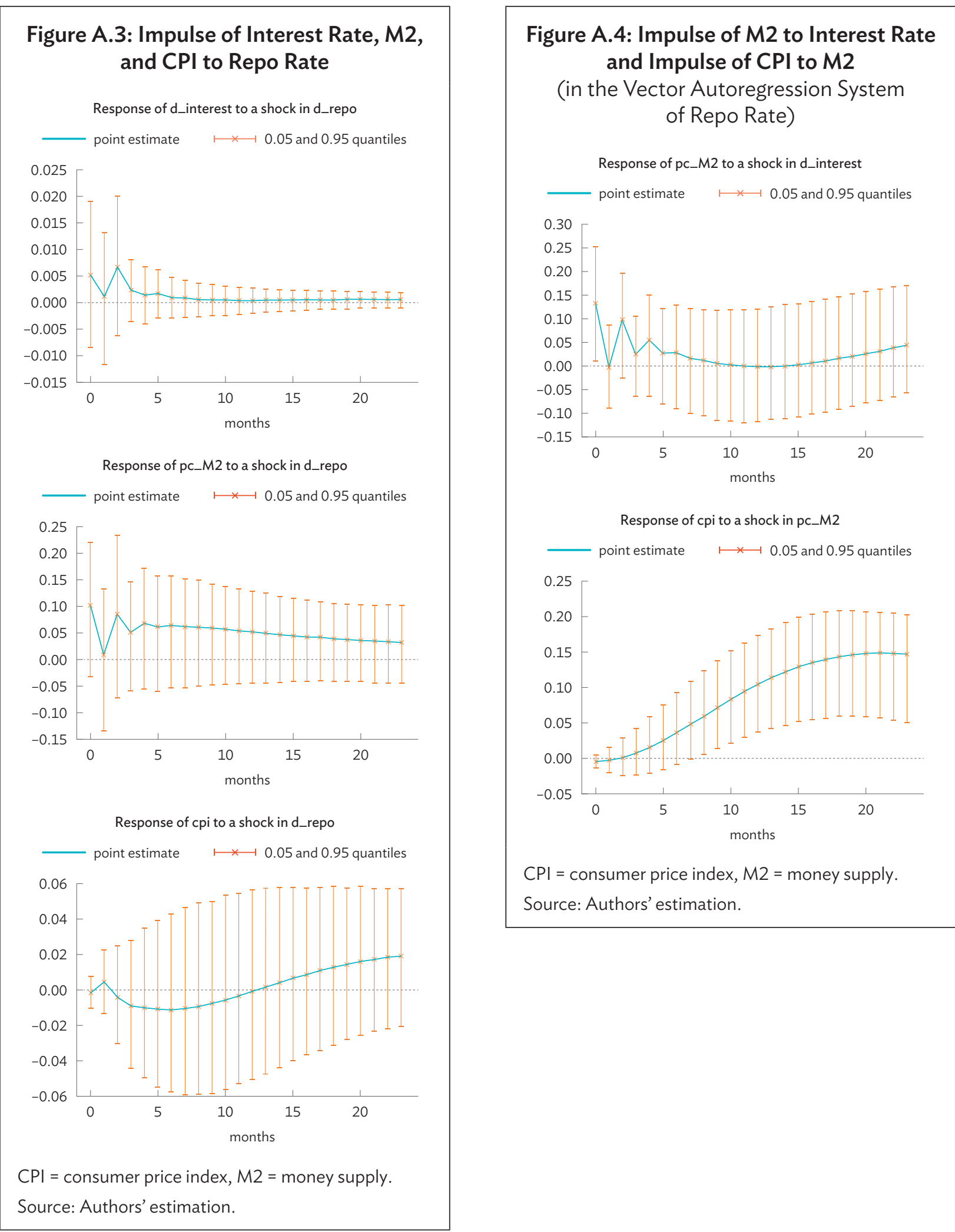


\section{National Savings Certificates as Policy Variable}

Figure A.5: Impulse of Interest Rate, $M 2$, and CPI to National Savings Certificate
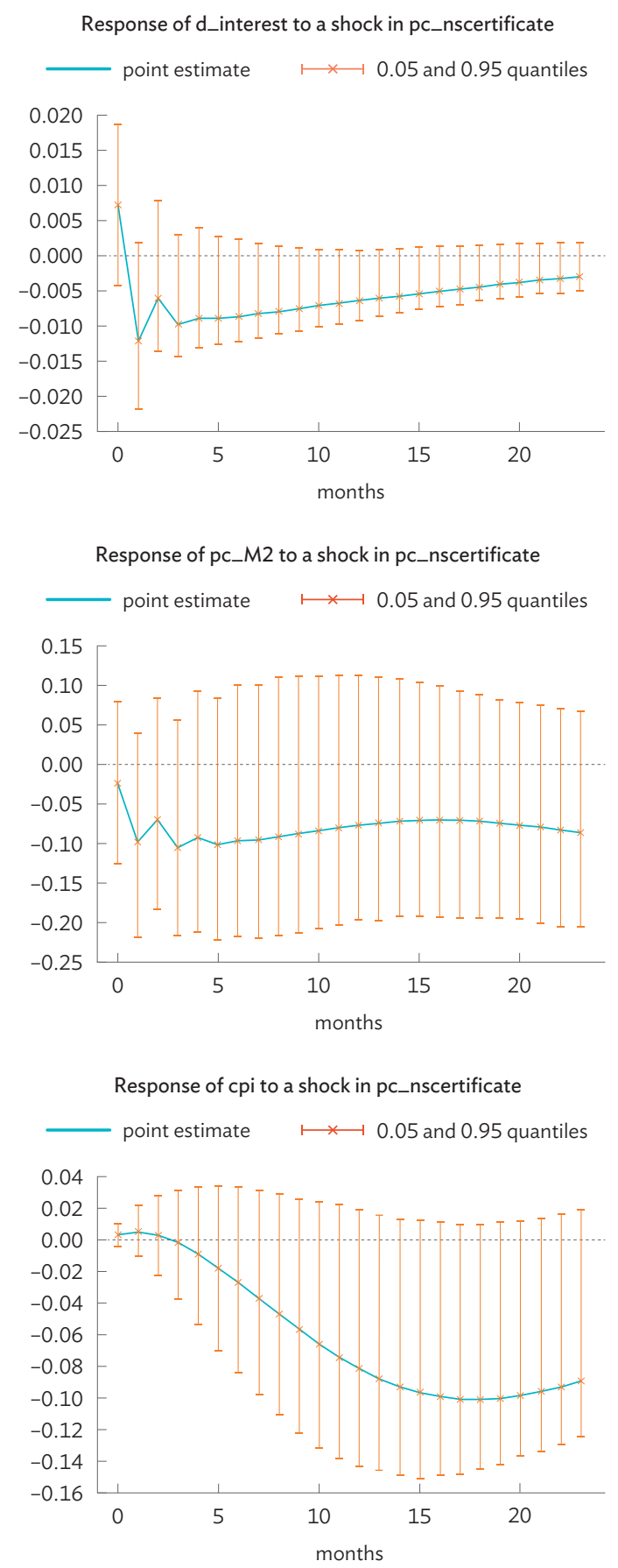

$\mathrm{CPI}=$ consumer price index, $\mathrm{M} 2$ = money supply. Source: Authors' estimation.

\section{Figure A.6: Impulse of $M 2$ to Interest Rate and Impulse of CPI to M2}

(in the Vector Autoregression System

of National Savings Certificate)

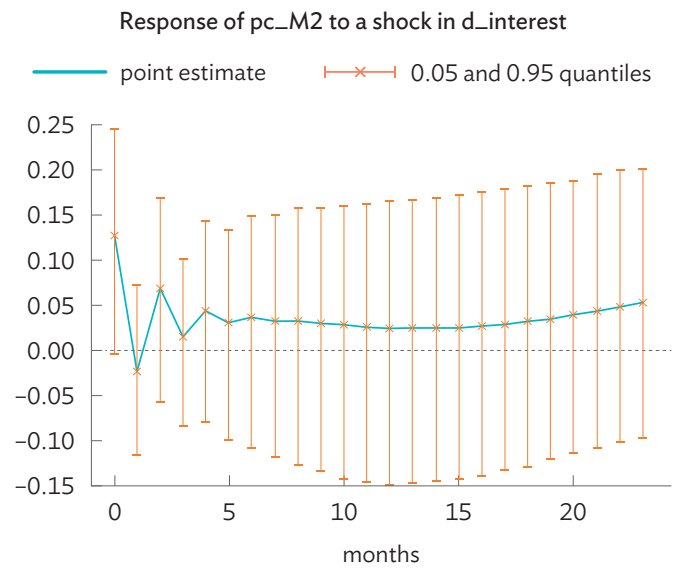

Response of cpi to a shock in pc_M2

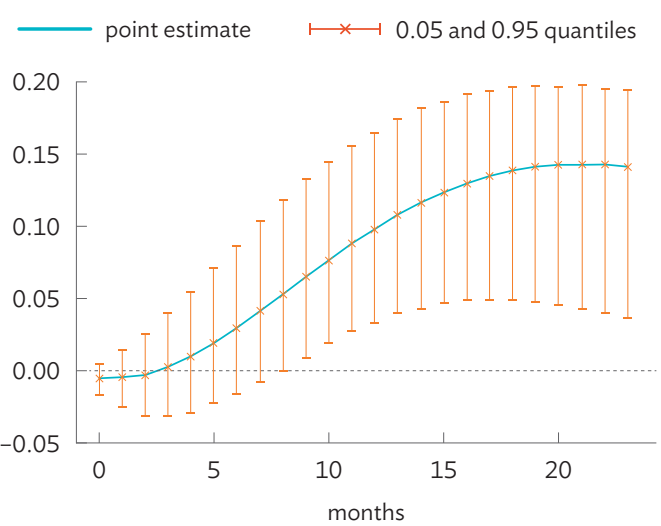

$\mathrm{CPI}=$ consumer price index, $\mathrm{M} 2$ = money supply.

Source: Authors' estimation. 


\section{REFERENCES}

Ahmed, S., and M. Islam. 2004. The Monetary Transmission Mechanism in Bangladesh: Bank Lending and Exchange Rate Channels. The Bangladesh Development Studies. 30(3/4): 31-87.

Boivin, J., M. Kiley, and F. Mishkin. 2010. How Has the Monetary Transmission Mechanism Evolved Over Time? NBER Working Paper. No. 15879. National Bureau of Economic Research.

Christiano, L., M. Eichenbaum, and C. Evans. 1999. Chapter 2 Monetary Policy Shocks: What Have We Learned and to What End? Handbook of Macroeconomics. Elsevier. Vol. 1. Part A: 65-148.

Égert, B., and R. MacDonald. 2009. Monetary Transmission Mechanism in Central and Eastern Europe: Surveying the Surveyable. Journal of Economic Surveys. Volume 23. Issue 2. 277-327.

Giordani, P. 2004. An Alternative Explanation of the Price Puzzle. Journal of Monetary Economics. 51(6): 1271-1296.

Goswami, G., and T. Ahmed. 2017. Testing Monetarist-Structuralist Controversy in Determining Inflation in Bangladesh. Tennessee State University, College of Business. Journal of Developing Areas. 51(3): 17-31.

Hanson, M. 2004. The 'Price Puzzle' Reconsidered. Journal of Monetary Economics. 51(7): 1385-1413.

International Monetary Fund (IMF). 2018. Selected Issues Paper. IMF Country Report No. 18/159.

- 2020. IMF Country Report No. 20/187.

Islam, A. 2012. Bangladesh Monetary Policy Transmission Mechanism: Asymmetric Responses, Inflation and Policy Time Lags. Savings and Development. 36: 91-107.

Karim, M. S. 2019. An Empirical Evaluation of Monetary and Fiscal Policy Effects in Bangladesh. ADB South Asia Working Paper Series. No. 66. http://dx.doi.org/10.22617/WPS190285-2.

Khundrakpam, J., and J. Rajeev. 2012. Monetary Policy Transmission in India: A Peep Inside the Black Box. RBI Working Paper Series. 2012(11): 1-45.

Mishra, P., and P. Montiel. 2012. How Effective Is Monetary Transmission in Low-Income Countries? A Survey of the Empirical Evidence. IMF Working Paper. 12(143).

Mishra, P., P. Montiel, and A. Spilimbergo. 2010. Monetary Transmission in Low Income Countries. IMF Working Paper. 10(223).

—. Monetary Transmission in Low-Income Countries: Effectiveness and Policy Implications. IMF Economic Review, (forthcoming).

Mishra, P., P. Montiel, P. Pedroni, and A. Spilimbergo. 2014. Monetary Policy and Bank Lending Rates in Low-Income Countries: Heterogeneous Panel Estimates. Journal of Development Economics. 111: 117-131.

Montiel, P. 1991. The Transmission Mechanism for Monetary Policy in Developing Countries Staff Papers. International Monetary Fund. 38(1): 83-108.

Rahman, M. N. et al. 2019. Impact of Monetary Policy on the Economic Growth of a Developing Country: An Empirical Study on Bangladesh Economy. https://ssrn.com/abstract=3391280; http://dx.doi. org/10.2139/ssrn.3391280.

Taylor, J. 1995. The Monetary Transmission Mechanism: An Empirical Framework. Journal of Economic Perspective. 9: 11-26. 


\section{Monetary Policy Transmission Mechanism of Bangladesh}

Understanding the effects of monetary policy on the economy is crucial in the study of macroeconomics and in the practice of policy making. This paper empirically examines the effectiveness of the monetary policy of the central bank of Bangladesh. In the case of Bangladesh Bank, the paper shows that while traditional tools (i.e., reserve money and repo rate) do not perform as predicted, the national savings certificate affects the economy of Bangladesh as if it were a monetary policy tool, weakening the effectiveness of the monetary policy transmission mechanism.

\section{About the Asian Development Bank}

ADB is committed to achieving a prosperous, inclusive, resilient, and sustainable Asia and the Pacific, while sustaining its efforts to eradicate extreme poverty. Established in 1966, it is owned by 68 members -49 from the region. Its main instruments for helping its developing member countries are policy dialogue, loans, equity investments, guarantees, grants, and technical assistance. 